\title{
SUBSTANTIATION OF THE COMPOSITION AND METHODS OF QUALITY CONTROL FOR "GENTA+" OINTMENT WITH THE SUCCINYL TANNIN ANTIRESISTANT COMPONENT
}

\author{
Mustafa Alhussein, A.V.Martynov \\ State Institution "Institute of Microbiology and Immunology named after I.I.Mechnikov \\ of the National Academy of Medical Sciences of Ukraine"
}

Key words: ointment; gentamicin; tannin; succinyl gallotannin; multiresistant microorganisms; antibiotic resistance

\begin{abstract}
The results of the design and selection of compositions of antimicrobial ointments containing gentamicin as the main active substance and succinyl gallotannin as an antiresistant component. The concentration of the latter was $0.001 \%$, had no direct antimicrobial effect, but blocked well the factors of microbial resistance and potentiated the effects of gentamicin. This composition showed antimicrobial properties against multiresistant strains of Pseudomonas aeruginosa and Staphylococcus in the experiment in vitro. According to the results of mathematical modeling the statistical hypothesis concerning the maximum mechanical stability of the ointment composition based on the carbomer with the penetration enhancer PEO-400 has been confirmed. The given composition is recommended for further development of an ointment on its basis for treating the second stage of the wound healing process complicated by multiresistant purulent infections. The low concentrations of the main active substances determine the economic prospects and expediency of the drug introduction into production.
\end{abstract}

Control of wound infections that are resistant to the action of antibiotics has become currently important [7]. It is associated both with spreading of nosocomial microbiota with multiple cross-resistance (multiresistant strains) in hospitals and with the weakening of the immune system of patients and, therefore, with a long-term "selection" of resistant strains in "aggressive" wound conditions [11]. Many ointments and gels are presented among drugs, which are used for treating the wound process of the II stage [13]. But the majority of antibacterial agents included in their composition are not effective long ago in relation to nosocomial infections. Wounds, which are infected with multiresistant forms of microorganisms, for example Pseudomonas aeruginosa, does not heal for a long time, and it often causes disability of patients. Lately there are tendencies concerning a considerable increase of the death rate from multiresistant nosocomial infections [12]. Especially this pattern is typical for post-operative rehabilitation period, which a patient spends exactly in the hospital. Therefore, control of nosocomial multiresistant wound infections is a very urgent task of modern medicine and pharmacy [9].

One of the areas of this control is deprivation of bacteria with resistance factors and as a consequence recovery of their sensitivity to the action of classical antimicrobial drugs. An example of such successful synergistic composition for antimicrobial medicines is the composition of Amoxiclav, which contains amoxicillin and antiresistant substance - clavulanic acid. The latter blocks enzyme, which destroys the penicillin ring in the amoxicillin structure [13]. Unfortunately, penicillins in the ointment formulation are relatively unstable and less effective. There is a well-known Gentamicin ointment which still has not lost its popularity thanks to the wide spectrum of action, relative efficiency at the II stage of the wound process. The concentration of the main active substance is very low and is $0.1 \%$, but imperfect formulation of the ointment composition do not allow to use it extensively in surgical practice: the vaseline-paraffin base harms the wound, causes embolism and removes badly from the wound when bandaging. In more than $60 \%$ of cases the resistant forms of bacteria make the treatment process with Gentamicin ointment noneffective [8].

As a result of our long-term research a drug, which can selectively interact with enzymes of bacteria resistance in the lowest doses and inhibit the activity of these enzymes without direct antimicrobic action in the absence of toxic effect on the human organism, has been developed. This drug belongs to chemically modified gallotannins. In previous studies we isolated the most active gallotannin - succinyl gallotannin, which was able to recover antibiotic sensitivity of multiresistant bacteria in the dose of $1 / 100$ from the antibiotic concentration [1]. Acylation of phenolic hydroxyls of the gallotannin molecule blocked its quick interaction with wound components and its inactivation of the antibiotic, but did not deprive its ability to intercalation to the protein globule of penicillinase and other enzymes present in the wound and blockade of their activity. The effectiveness of native plant enzymes in treatment of purulent wounds is shown in the research [10].

Thus, the aim of our research was to substantiate the formulation and quality control methods for "Genta-plus" ointment, to select the most effective ointment composition with the maximal antimicrobial action in 
Formulation of bases for compositions of local application for developing the gentamicin ointment with the antiresistant component GENTA+

\begin{tabular}{|c|c|c|c|c|c|c|c|}
\hline \multirow{2}{*}{ The composition ingredients } & \multicolumn{7}{|c|}{ The number of the composition } \\
\hline & 1 & 2 & 3 & 4 & 5 & 6 & 7 \\
\hline Sodium carboxymethylcellulose & 5 & & & & & & \\
\hline Glycerine & 10 & 5 & & 13.5 & & & 5 \\
\hline Carbomer & & 0.5 & 0.5 & & 0.5 & & \\
\hline Sodium hydroxide, $10 \%$ & & 0.5 & 0.5 & & 0.5 & & \\
\hline Isopropanol & & & 25 & & & & \\
\hline Glycerol monostearate & & & & 25 & & & \\
\hline Potassium hydroxide, $10 \%$ & & & & 0.5 & & & \\
\hline Vaseline oil & & & & & 22 & & \\
\hline Tween-80 & & & & & 8 & & \\
\hline Polawax & & & & & 4 & 15 & 12 \\
\hline Propylene glycol & & & & & 4 & & \\
\hline PEO-400 & & & & & & 25 & \\
\hline Castor oil & & & & & & & 25 \\
\hline Distilled monoglycerides & & & & & & & 8 \\
\hline Purified water & & & & To 100 & & & \\
\hline
\end{tabular}

relation to multiresistant forms (strains) of microorganisms.

\section{Materials and Methods}

The following reagents were used in the research: succinyl gallotannin (SGT) (SI "Institute of Microbiology and Immunology named after I.I.Mechnikov of the NAMS of Ukraine, Kharkiv) as an antiresistant component; Carbomer (carbopol) grade 934 ("BF Goodrich", USA) as a gel former; gentamicin ("Shing-su chemical", China) as an active substance; PEO-400 (Merck, USA) as a penetration enhancer of antibiotics and antiresistant agent; triethanolamine (Sigma, USA) as an activator of carbopol polymerization; suttocide (Garmill, USA) as a preservative. Glycerine, isopropanol, stearic acid, potassium hydroxide, vaseline oil, Tween-80, emulsifier No.1, propylene glycol, polymethylsiloxane 200 , castor oil, distilled monoglycerides were used only for mathematical modeling and according to literary data (by variance analysis and Duncan rank test). The antimicrobial activity of the composition obtained was studied on multiresistant strains from the Clinical Microbiology laboratory and the laboratory of Biochemistry of Microorganisms and Culture Media of the State Institution "Institute of Microbiology and Immunology named after I.I.Mechnikov of the National Academy of Medical Sciences of Ukraine and such strains as $S$. aureus poly2008, P. aeruginosa Port 293, C. albicans rts232, A. niger rs33. All strains mentioned were resistant to the action of the corresponding antibiotics and the preservative suttocide in the concentration of $0.2 \%$. The study of the antimicrobial properties of the composition was conducted according to the standard methods. The use of the main active substances in the lowest concentrations caused the choice of the composition formulation. Planning (modeling) is based on the effect of "mechanical stability", which is measured on a "Reotest-2" rotational viscometer and correlates with different formulations of the base compositions. In the concentrations of
$0.1 \%$ of gentamicin and $0.001 \%$ of succinyl gallotannin the main active substances did not reveal any effect on rheological and other values of the composition.

\section{Results and Discussion}

Along with the active substance, excipients provide the pharmacological effect needed [6]. Thus, the first stage was to plan the experiment and to select the composition of the base. The second stage of our research was the study of the most stable composition in order to reveal the antimicrobial activity in comparison with pure gentamicin. The preservative suttocide in the concentration of $0.2 \%$ did not reveal the antimicrobial activity in relation to multiresistant strains.

As carriers for the ointment being developed the bases-carriers, which are widely used in manufacture of soft medicinal dosage forms and cosmetic products, do not cause allergic and sensitizing effects after application, they are available for producer and well described in literature. The formulation of the compositions is given in Tab. 1 .

For all compositions obtained the "mechanical stability" was determined as an objective quantitative indicator of the ointment rheological evaluation. The "mechanical stability" as an indicator for mathematical modeling has been selected due to the fact that structuremechanical properties of ointments are one of the most important for providing the form quality, ability to active substances release and ability to application [4]. The results are given in Tab. 2 .

Modeling and variance analysis of the results showed a considerable effect of the type of the base on mechanical stability of the compositions (Tab. 3).

Variance analysis by Duncan rank test [3] gave a chance to outline the effect of the compositions' formulation on the main factor - "mechanical stability". In general, compositions No.1, 2, 3, 5, 6 were the most stable. Among them compositions 1,2 and 6 can be referred to one aggregate by stability. Due to the fact that the presence of the penetration enhancer PEO-400 
Rheological properties of samples of the compositions with gentamicin-containing ointments

\begin{tabular}{|c|c|c|c|c|c|}
\hline $\begin{array}{c}\text { The number } \\
\text { of the composition }\end{array}$ & \multicolumn{3}{|c|}{ The value of "mechanical stability" } & The average value & $\begin{array}{c}\text { Standard } \\
\text { deviation }\end{array}$ \\
\hline 1 & 1.00 & 1.02 & 1.02 & 1.01 & 0.01 \\
\hline 2 & 1.09 & 1.11 & 1.13 & 1.11 & 0.01 \\
\hline 3 & 1.20 & 1.30 & 1.24 & 1.25 & 0.04 \\
\hline 4 & 4.50 & 4.70 & 4.50 & 4.57 & 0.22 \\
\hline 5 & 1.41 & 1.45 & 1.47 & 1.44 & 0.02 \\
\hline 6 & 2.08 & 2.00 & 2.04 & 2.04 & 0.03 \\
\hline 7 & 1.80 & 1.90 & 1.93 & 1.28 & 0.56 \\
\hline
\end{tabular}

is desirable for the composition, therefore, for future research composition 6 has been selected and for comparison of the effects - compositions 1 and 2. The compositions formed contained the classic concentration of gentamicin $-0.1 \%$ and the modeled concentration of SGT $-0.001 \%$. The second group for comparison was the same compositions, but without SGT. Tab. 4 and 5 present the results of comparison of the antimicrobial effects of the compositions studied.

As it can be seen from Tables 4 and 5, the composition without the antiresistant component in its formulation did not have antimicrobial properties in relation to multiresistant strains of Staphylococcus and Pseudomonas aeruginosa and did not show any antifungal effects in relation to fungi of Candida and aspergilli. In addition, the similar composition with succinyl gallotannin completely inhibited the growth of drug-resistant
Table 3

The results of statistical processing of results by the analysis-of-variance method according to Duncan rank test

\begin{tabular}{|l|c|c|c|c|}
\hline Variation & Value & $\begin{array}{c}\text { Degrees } \\
\text { of freedom }\end{array}$ & $\begin{array}{c}\text { Variance } \\
\text { estimate }\end{array}$ & $\mathrm{F}$ \\
\hline External & 27.6 & 6 & 4.6 & \multirow{2}{*}{88.189} \\
\hline Internal & 0.7302 & 14 & 0.05216 & \\
\hline General & 28.33 & 20 & & \\
\hline
\end{tabular}

forms of Staphylococcus and Pseudomonas aeruginosa, but did not reveal any antifungal effects. As we have found previously, succinyl gallotannin in such concentration $(0.001 \%)$ does not show any antimicrobial and antifungal effects, but only blocks exogenous factors of antibiotics resistance of bacteria of the protein nature.

Table 4

The antimicrobial activity of the classic $0.1 \%$ gentamicin ointment on resistant forms of microorganisms (without suttocide in the composition)

\begin{tabular}{|c|c|c|c|c|c|c|}
\hline \multirow{3}{*}{$\begin{array}{c}\text { Exposure time } \\
\text { in the presence } \\
\text { of microorganisms } \\
\text { ( } 1 \mathrm{~g} \text { of the ointment } \\
\text { per } 5 \mathrm{ml} \text { of the medium) }\end{array}$} & \multicolumn{2}{|c|}{$\begin{array}{c}\text { Requirements of Ph. Eur. - } 2012 \\
\text { (Criterion B) }\end{array}$} & \multicolumn{4}{|c|}{ The number of microorganisms, CFU/ml } \\
\hline & $\begin{array}{l}\text { The number } \\
\text { of bacteria }\end{array}$ & $\begin{array}{c}\text { The number } \\
\text { of fungi }\end{array}$ & $\begin{array}{l}\text { S. aureus } \\
\text { poly-2008 }\end{array}$ & $\begin{array}{c}\text { P. aeruginosa } \\
\text { Port } 293\end{array}$ & $\begin{array}{l}\text { C. albicans* } \\
\text { rts } 232\end{array}$ & $\begin{array}{l}\text { A. niger } \\
\text { rs33 }\end{array}$ \\
\hline & $\mathrm{CFU} / \mathrm{ml}$ & $\mathrm{CFU} / \mathrm{ml}$ & $8.90 \cdot 10^{5}$ & $5.90 \cdot 10^{6}$ & $1.50 \cdot 10^{5}$ & $1.80 \cdot 10^{5}$ \\
\hline 2 days & $\mathrm{HP}$ & $\mathrm{HP}$ & $8.21 \cdot 10^{5}$ & $5.50 \cdot 10^{6}$ & $1.11 \cdot 10^{5}$ & $1.11 \cdot 10^{5}$ \\
\hline 7 days & $\mathrm{HP}$ & $\mathrm{HP}$ & $1.59 \cdot 10^{4}$ & $1.47 \cdot 10^{4}$ & $5.00 \cdot 10^{4}$ & $1.70 \cdot 10^{4}$ \\
\hline 14 days & $\mathrm{HP}$ & $\mathrm{HP}$ & $1.50 \cdot 10^{3}$ & $6.56 \cdot 10^{2}$ & $6.50 \cdot 10^{2}$ & $7.00 \cdot 10^{2}$ \\
\hline 28 days & $\mathrm{HP}$ & $\mathrm{HP}$ & $5.70 \cdot 10^{2}$ & $1.15 \cdot 10^{2}$ & $3.20 \cdot 10^{2}$ & $2.70 \cdot 10^{5}$ \\
\hline
\end{tabular}

* - Given for control of the absence of antifungal properties in the composition.

Table 5

The antimicrobial activity of $0.1 \%$ GENTA + ointment containing succinyl gallotannin as an antiresistant component on the resistant forms of microorganisms (without suttocide in the composition)

\begin{tabular}{|c|c|c|c|c|c|c|}
\hline \multirow{2}{*}{$\begin{array}{c}\text { Exposure time } \\
\text { in the presence } \\
\text { of microorganisms } \\
\text { (1 } \mathrm{g} \text { of the ointment per } \\
5 \mathrm{ml} \text { of the medium) }\end{array}$} & \multicolumn{2}{|c|}{$\begin{array}{l}\text { Requirements of Ph. Eur. - } 2012 \\
\text { (Criterion B) }\end{array}$} & \multicolumn{4}{|c|}{ The number of microorganisms, CFU/ml } \\
\hline & $\begin{array}{c}\text { The number } \\
\text { of bacteria } \\
\text { CFU/ml }\end{array}$ & $\begin{array}{c}\text { The number } \\
\text { of fungi } \\
\text { CFU/ml }\end{array}$ & $\begin{array}{l}\text { S. aureus } \\
\text { poly-2008 }\end{array}$ & $\begin{array}{c}\text { P.aeruginosa } \\
\text { Port } 293\end{array}$ & $\begin{array}{c}\text { C. albicans* } \\
\text { rts } 232\end{array}$ & $\begin{array}{c}\text { A. } \text { niger }^{*} \\
\text { rs33 }\end{array}$ \\
\hline Day of introduction & - & - & $8.00 \cdot 10^{5}$ & $5.00 \cdot 10^{6}$ & $1.00 \cdot 10^{5}$ & $1.11 \cdot 10^{5}$ \\
\hline 2 days & $\mathrm{HP}$ & $\mathrm{HP}$ & $\mathrm{HP}$ & $\mathrm{HP}$ & $2.70 \cdot 10^{5}$ & $1.56 \cdot 10^{5}$ \\
\hline 7 days & $\mathrm{HP}$ & $\mathrm{HP}$ & $\mathrm{HP}$ & $\mathrm{HP}$ & $5.00 \cdot 10^{4}$ & $1.70 \cdot 10^{4}$ \\
\hline 14 days & $\mathrm{HP}$ & $\mathrm{HP}$ & $\mathrm{HP}$ & $\mathrm{HP}$ & $6.50 \cdot 10^{2}$ & $7.00 \cdot 10^{2}$ \\
\hline 28 days & $\mathrm{HP}$ & $\mathrm{HP}$ & $\mathrm{HP}$ & $\mathrm{HP}$ & $3.20 \cdot 10^{2}$ & $2.70 \cdot 10^{5}$ \\
\hline
\end{tabular}

* - Given for control of the absence of antifungal properties in the composition. 


\section{CONCLUSIONS}

The choice of a carbomer gel with the penetration enhancer PEO-400 in its composition is optimal for "Genta+" ointment as the base.
Taking into consideration of the results obtained the given composition (after adding suttocide) can be recommended for creating an antiresistant ointment for treating severe forms of purulent complications in surgery.

\section{REFERENCES}

1. Альхуссейн Али Мустафа, Мартынов А.В. // Укр. журн. клін. та лабораторної медииини. - 2013. T. 8, №1. - C. 76-78.

2. Герд Кути. Косметические кремы и эмульсии: состав, получение, методы испытаний / Пер. с нем. А.С.Филипова; под ред. М.Ю.Плетнева. - М.: ООО «Фирма Клавель», 2004. - 272 c.

3. Грошовый Т.А., Маркова Е.В., Головкин В.А. Математическое планирование эксперимента в фармаиевтической технологии. Планы дисперсионного анализа. - К.: Вища шк., 1992. - 187 c.

4. Лысокобылка А.А., Безуглая Е.П., Ляпунов Н.А. // Фармаком. - 2001. - №4. - С. 1-7.

5. Малкин А.Я., Исаев А.И. Реология: конщепџии, методы, приложения. - С.Пб.: Профессия, 2007. - 560 с.

6. Фармацевтические и биологические аспекты мазей / И.М.Периев, А.М.Котенко, О.В.Чуешов, Е.Л.Халеева. - Х.: Изд-во НфаУ; Золотые страницы, 2003. - 288 с.

7. Daeschlein G. // Int. Wound J. - 2013. - Suppl. 1. - P. 9-14.

8. Fukutsuji K., Yamada S., Harada T. // Med. Mol. Morphol. - 2013. - Vol. 46, №2. - P. 70-76.

9. Iwaki M., Noguchi N., Nakaminami H. et al. // Yakugaku Zasshi. - 2011. - Vol. 131, №11. - P. 1653-1659.

10. Li K., Diao Y., Zhang H. et al. // BMC Complement. Altern. Med. - 2011. - Vol. 11. - P. 86-89.

11. Lode H.M., Stahlmann R., Kresken M. // Zentralbl. Chir. - 2013. - Vol. 138, №5. - P. 549-553.

12. López M.P., Capafons R.S., Cruz G.D., Garriga B.R. // Farm. Hosp. - 2013. - Vol. 37, №4. - P. 339-340.

13. Neidrauer M., Ercan U.K., Bhattacharyya A. et al. // J. Med. Microbiol. - 2014. - Vol. 63, Pt 2. - P. 203-109.

\section{ОБГРУНТУВАННЯ СКЛАДУ ТА МЕТОДІВ КОНТРОЛЮ ЯКОСТІ МАЗІ «ГЕНТА+»}

3 АНТИРЕЗИСТЕНТНИМ КОМПОНЕНТОМ СУКЦИНІЛТАНІДОМ

Мустафа Альхусейн, А.В.Мартинов

Ключові слова: мазь; гентаміцин; танід; сукцинілгалотанін; полірезистентні

мікроорганізми; антибіотикорезистентність

Представлені результати проектування та відбору композицій антимікробних мазей, що містять гентаміцин як основну діючу речовину та антирезистентний компонент сукцинілгалотанін. Концентрація останнього складала 0,001\%, не мала прямого антимікробного впливу, але добре блокувала фрактори резистентності мікроорганізмів та потенціювала ефекти гентаміцину. Вказана композиція проявила антимікробні властивості по відношенню до полірезистентних итамів синьогнійної палички та стафрілокока в експерименті. За результатами математичного моделювання була підтверджена статистична гіпотеза про найбільшу механічну стабільність композиції мазі на основі карбомера з провідниковим компонентом поліетиленоксидом-400. Вказана композиція рекомендована для подальшої розробки на ії основі мазі для лікування другої стадії ранового процесу, ускладненого полірезистентними гнійними інфекціями. Низькі концентрації основних діючих речовин обумовлюють економічну перспективність та доцільність впровадження вказаного засобу у виробництво.

\section{ОБОСНОВАНИЕ СОСТАВА И МЕТОДОВ КОНТРОЛЯ КАЧЕСТВА МАЗИ «ГЕНТА+» С АНТИРЕЗИСТЕНТНЫМ КОМПОНЕНТОМ СУКЦИНИЛТАНИДОМ Мустафа Альхусейн, А.В.Мартынов}

Ключевые слова: мазь; гентамицин; таннид; сукцинилгаллотаннин; полирезистентные микроорганизмы; антибиотикорезистентность

Представлены результаты проектирования и отбора композиций противомикробных мазей, содержащих в качестве основного действующего вещества гентамицин и сукцинилгалотанин в качестве антирезистентного компонента. Концентрация последнего составляла 0,001\%, не имела прямого антимикробного эфрфекта, но хорошо блокировала фракторы резистентности микроорганизмов и потенцировала эффректы гентамицина. Указанная композиция проявила антимикробные свойства по отношению к полирезистентным штаммам синегнойной палочки и стафрилококка в эксперименте in vitro. По результатам математического моделирования была подтверждена статистическая гипотеза о максимальной механической стабильности композиции мази на основе карбомера с усилителем всасывания полиэтиленоксидом-400. Указанная композиция рекомендована нами для дальнейшей разработки на ее основе мази для лечения второй стадии раневого процесса, осложненного полирезистентными гнойными инфрекциями. Низкие концентрации основных действующих веществ обусловливают экономическую перспективность и целесообразность внедрения указанного средства в производство. 